\title{
Regime destabilisation as the flipside of energy transitions: Lessons from the history of the British coal industry (1913-1997)
}

\author{
Bruno Turnheim*, Frank W. Geels \\ SPRU, University of Sussex, BN1 9RH, UK
}

\section{H I G H L I G H T S}

- We investigate the destabilisation of existing regimes and industries.

- We conceptualise destabilisation as a multi-dimensional and enacted phenomenon.

- We mobilise two historical cases of the British coal industry.

- We develop ten original lessons on destabilisation.

- We provide insights of relevance to transitions to low-carbon energy systems.

\section{A R T I C L E I N F O}

\section{Article history:}

Received 30 October 2011

Accepted 26 April 2012

Available online 9 June 2012

Keywords:

Industry destabilisation

Socio-technical transitions

Coal

\begin{abstract}
A B S T R A C T
This paper investigates a neglected aspect of the transitions literature: the destabilisation of existing regimes and industries. It presents an analytical perspective that integrates four existing views on destabilisation and conceptualizes the process as a multi-dimensional and enacted phenomenon involving technical, economic, political, and cultural processes. This perspective is illustrated with two historical cases of the British coal industry (1913-1967, 1967-1997). These cases are also used to articulate five lessons regarding the overall destabilisation process and five lessons regarding the economic and socio-political environments of industries. The conclusion section translates the historical lessons into insights with relevance for the contemporary challenge of climate change and transitions to low-carbon energy systems.
\end{abstract}

(c) 2012 Elsevier Ltd. All rights reserved.

\section{Introduction}

This paper contributes to the debate on socio-technical transitions to sustainability (Geels, 2002; Smith et al., 2005; Geels and Schot, 2007; Fouquet, 2010). Most scholars in this debate focus on emergence of radical innovations such as wind turbines, biofuels, and electric vehicles. The destabilisation of existing regimes is assumed to happen along the way and has received far less analytical attention. This paper aims to address this gap in the transitions debate, focusing in particular on the destabilisation of incumbent industries. It thus turns the 'normal' focus (on novelty and innovation) upside down and investigates what transitions look like from the incumbents' perspective.

The theoretical relevance is that much is known about path dependence and lock-in (Arthur, 1989; Unruh, 2000), but far less about the unlocking of deeply entrenched industries and systems. Evolutionary economics (Nelson and Winter, 1982) suggests that

\footnotetext{
* Corresponding author.

E-mail address: brunoturnheim@gmail.com (B. Turnheim).
}

firms-in-an-industry are locked in by technological regimes, which contain cognitive routines and technical knowledge and capabilities. Neo-institutional theory suggests that lock-in also stems from shared beliefs, taken-for-granted assumptions, and industry mindsets (Phillips, 1994), from regulatory institutions (Scott, 1995) and from shared norms, identities and missions (Dutton and Dukerich, 1991). Geels (submitted for publication) proposed the concept of 'industry regime' to capture these different core elements. We draw on this concept to delineate the phenomenon of destabilisation.

Stability generally refers to the continuity of key attributes of an entity. For industries, stability can be conceptualized as the reproduction of the core elements of the industry regime. Industry destabilisation can therefore be described as the process of weakening reproduction of core regime elements. Phrased differently, destabilisation is the process through which an existing regime loses its grip on firms-in-an-industry. This may happen either because industry actors reorient themselves to a new regime (reminiscent to Lewin's (1947) change model of unfreeze-changerefreeze) or because incumbent actors are replaced by new entrants (and a new regime). 
As a step towards deeper understanding, we suggest that destabilisation is a multi-dimensional process. With regard to stability, different theories highlight different aspects of regime reproduction: (a) evolutionary and industrial economics argue that actors need resources to reproduce regime elements, which derive from commercial transactions in economic environments; (b) neo-institutional theory argues that reproduction depends on legitimacy (and political and public support), which derives from the fit between the industry regime and wider societal institutions (Oliver, 1992); (c) performative approaches in management (Feldman, 2003) and sociology (Giddens, 1984) argue that reproduction entails endogenous enactment, commitment, and confidence in the regime's viability. Building on these theories, we suggest that destabilisation may result from a weakening flow of resources, decreasing public legitimacy and eroding endogenous commitment.

The main goal of the paper is to develop and test a conceptual framework that further clarifies the causal mechanisms that underlie these processes. The second goal is to articulate lessons with regard to destabilisation in low-carbon transitions. The rationale is that the topic of destabilisation has practical relevance for the societal debate on climate change and transitions to low-carbon systems. At present, the diffusion of renewable energy options appears to proceed too slowly to keep climate change within the envisaged two degrees limit. The deliberate destabilisation and decline of fossil fuel based industries may play a productive role in sustainability transitions, because it would create more space for renewables and accelerate their diffusion. A better understanding of destabilisation processes may therefore offer relevant lessons for low-carbon transitions.

Low-carbon transitions are of a particular kind because they concern a normative and collective good problem. They are 'purposive transitions', which are "deliberately intended and pursued from the outset to reflect an explicit set of societal expectations or interests" (Smith et al., 2005:1502). Because private actors have limited incentives to address societal problems (because of market failures and free-rider problems), it is likely that social movements, public opinion, and policy makers play important roles in purposive transitions. Our conceptualisation of industry destabilisation will therefore also pay attention to societal and environmental problems and cultural and political responses.

The bulk of the paper addresses the first goal. Section 2 briefly discusses insights from existing literatures and presents an integrative conceptual framework on industry destabilisation that provides a more concrete operationalisation of different causal mechanisms. In particular, it distinguishes various external pressures and endogenous responses, which are mediated by an industry regime. The framework acknowledges technical, economic, political, normative and cultural dimensions. Sections 3 and 4 present findings from two historical case studies of the British coal industry, which illustrate the framework. The first case (1913-1967) is about the transition from coal as omnipresent fuel to a four-fuel economy (coal, oil, nuclear, gas). During this transition, the coal industry lost most of its markets and reoriented towards a new regime (based on new technical capabilities, beliefs, mission and regulations). The second case (1967-1997) concerns coal and electricity generation, which increasingly formed the industry's lifeline. Destabilisation in this segment was due to major changes in the economic policy framework (Thatcher's liberalisation), competition from cheap international coal and the 'dash for gas' which caused a major decline in British coal.

We have chosen historical cases, because they allow the investigation of fully realised destabilisation processes (from beginning to end). Section 4 derives specific lessons about destabilisation, with a view to informing current debates about low-carbon transitions. Both historical cases implicate environmental problems (coal smoke and acid rain), which was an additional reason for their selection.

The reason for selecting the British coal industry is that it is an exemplar of deeply embedded, politically and societally relevant industries. Coal was used in households, factories, railways and steamships, iron and steel industries, gas works, electric power stations, and collieries. In 1913, coal was the single largest employer of industrial labour, providing jobs to $10 \%$ of the occupied male population (Dintenfass, 1992). The sale of coal abroad accounted for $10 \%$ of the total value of British exports. The coal industry thus played a central role in economic, political and social considerations. In that sense, there are similarities to the contemporary car, oil, electricity, and gas industries. There are also two differences due to the fact that coal was a nationalized industry from 1946 to 1994: (1) in this period, the industry was (1) a single organisation rather than a population of firms, (2) major government influence.

Section 3 describes overall developments for both cases and analyses the match and mismatch with the conceptual model. Section 4 presents more specific lessons from both cases, organised along the lines of the conceptual framework. Section 5 draws conclusions and addresses the second goal by discussing the relevance of lessons to low-carbon transitions.

\section{Conceptual framework}

\subsection{Extant literature}

To elaborate our initial understanding of industry destabilisation, we build upon insights about causal mechanisms in four literatures. First, the (neo-Schumpeterian) innovation studies literature proposes that destabilisation is caused by 'disruptive' innovations, which lead to the decline of existing industries and undermine the resource base of existing regimes (Christensen, 1997). Second, scholars in industrial economics (Lorenz, 1994) and economic history (Dintenfass, 1992) propose that destabilisation is caused by other economic factors such as shrinking markets, changing markets, and new entrants that outcompete the focal industry (e.g., because of lower costs or more efficient process technologies). Both literatures see economic performance problems and shrinking financial resources as core dimensions of destabilisation. Third, institutional theorists see destabilisation as a de-legitimisation process (Scott, 1995; Oliver, 1992). The core mechanism is that a loss of political or cultural legitimacy weakens the support from important stakeholders (policy makers, wider publics). Fourth, management and organisational scholars propose

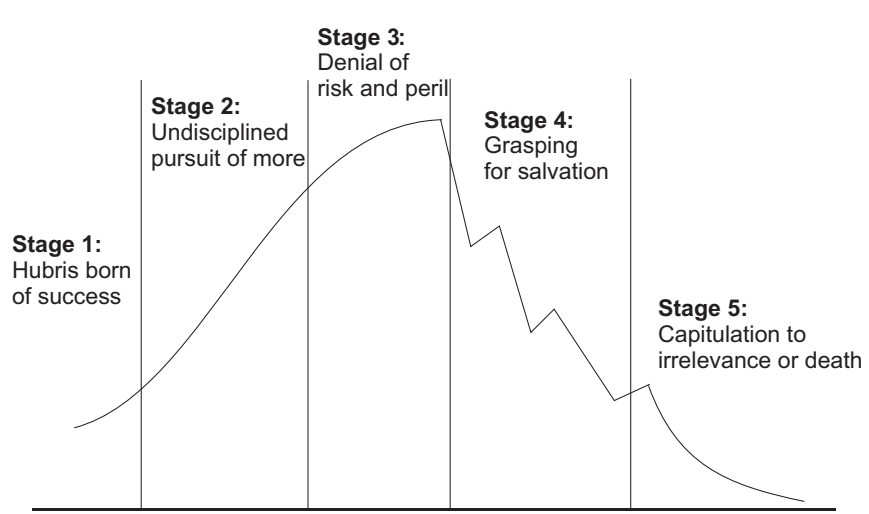

Fig. 1. The five stages of decline (Collins, 2009:20). 
Table 1

Stages of organizational decline and corresponding organizational action (Weitzel and Jonsson, 1989:97).

\begin{tabular}{|c|c|}
\hline Stages & Organizational action \\
\hline 1. Blinded & Failure to anticipate or detect pressure toward entropy; decline begins. \\
\hline 2. Inaction & Failure to decide on corrective action; decline becomes noticeable. \\
\hline 3. Faulty action & Faulty decisions; faulty implementation of decisions. \\
\hline 4. Crisis & Given faulty-action stage and unforgiving environment, last chance for survival. Given forgiving environment, slow erosion. \\
\hline 5. Dissolution & Given crisis stage and unforgiving environment, rapid demise. Given forgiving environment, slow demise. \\
\hline
\end{tabular}

'inside-out' views that address the enactment of destabilisation from a firm-oriented perspective. They see destabilisation as a longitudinal decline process with several stages (Fig. 1). The causes for decline (from stage 3 ) often have origins in earlier stages.

This fourth literature does not see destabilisation as the inevitable outcome of external pressures, but also as involving endogenous and strategic response to performance problems. Weitzel and Jonsson, (1989) distinguish five phases and argue that the lack of appropriate response causes organization to decline (Table 1 ). In the early stages, actors tend to remain committed to the existing template or regime. But when decline leads to persistent losses, commitment is likely to weaken when actors increasingly question the viability of the existing regime.

These four different views highlight different aspects of destabilisation, which should thus be seen as multi-dimensional, involving interacting economic, technological, political, cultural, and business dimensions. Furthermore, the brief review suggests that industry destabilisation is best seen as a longitudinal process that involves both external pressures (the first three views) and endogenous enactment (the fourth view). With regard to external pressures, we can also distinguish between uncoordinated, decentralized and market driven causes (first two views) and more purposive, meaningful and coordinated causes (third view). ${ }^{1} \mathrm{We}$ aim to position these insights and distinctions in an integrative triple embeddedness framework of industries (Section 2.2), which we subsequently use to articulate our understanding of industry destabilisation (Section 2.3).

\subsection{Triple embeddedness framework}

The triple embeddedness framework (TEF) of industrial change (Geels, submitted for publication) conceptualises industry actors as embedded in two selection environments (economic and sociopolitical), and structurated by field-specific institutions (industry regimes) (Fig. 2).

The economic environment encompasses supply-chains and markets. Relevant social groups include suppliers, customers, new entrants, and technological alternatives (Porter, 1980). Resource flows concern goods and services, which are assessed according to economic criteria (price, cost, technical performance, efficiency).

The socio-political environment contains non-commercial relationships between industry and non-market actors, such as policymakers, wider publics, and social movements. The main selection criteria are social fitness and legitimacy, which determine the industry's 'license to operate' (Fligstein, 1996). Legitimacy arises from adherence to formal institutions (policies, regulations) and informal institutions public values, expectations.

Building on sociological and institutional theories (Giddens, 1984; Scott, 1995), the TEF also sees industry actors as structurated by an 'industry regime' (Geels, submitted for publication), which is a set of industry-specific institutions (Haveman and Rao, 1997) that enable and constrain behaviour and action. Industry regimes

\footnotetext{
${ }^{1}$ We want to thank an anonymous reviewer for this distinction.
}

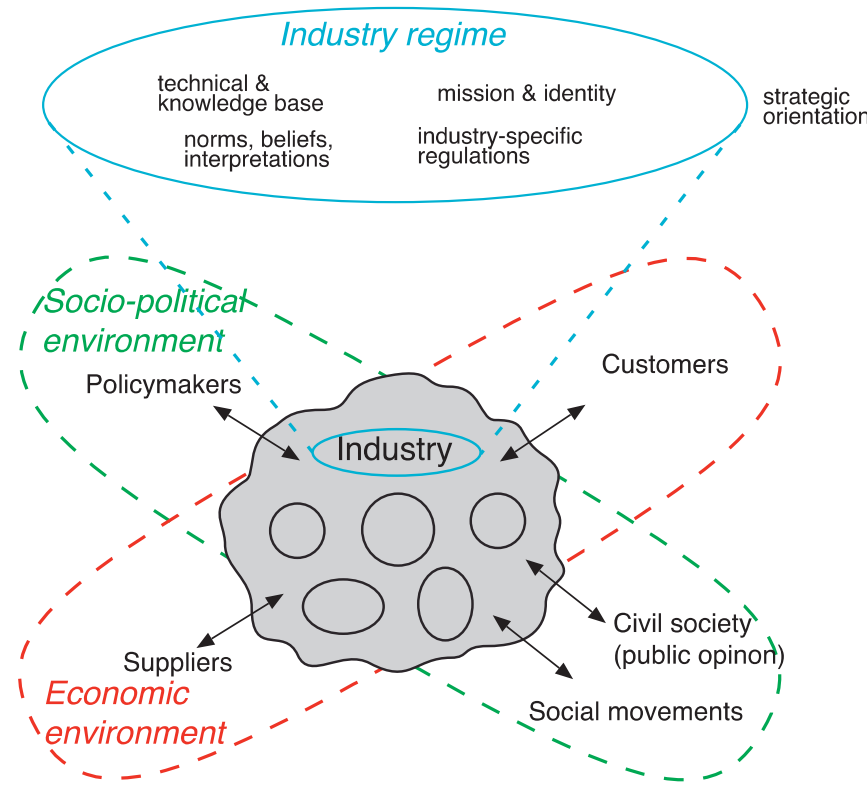

Fig. 2. Triple embeddedness framework of industries.

Source: (adapted from Geels, submitted for publication).

are usually stable, because of various lock-in mechanisms and commitments:

1) Commitment to cultural-cognitive institutions (mental maps, beliefs) focuses the interpretations of actors, blinding them to developments outside their focus. Cognitive inertia may lead to mis-interpretation of external threats and delays in response strategies (Tripsas and Gavetti, 2000).

2) Commitment to mission and identity refrains industry actors from changing their strategic and societal positioning (Dutton and Dukerich, 1991).

3) Commitment to the existing technical competencies creates resistance against technological discontinuities (Christensen, 1997).

4) Industry actors are committed to industry-specific regulatory institutions through compliance mechanisms (Scott, 1995). These institutions constrain the behavior of industries with incentives and disincentives.

Industry actors are influenced by external pressures, but also respond strategically to them. These response strategies are guided by industry regimes. The main strategies towards various environments are the following.

a) Economic positioning strategies focus on the position of industries in the economic environment (Porter, 1980). These strategies include supply chain management, operations management, marketing and sales.

b) Innovation/technology strategies include R\&D, knowledge management, and product development alliances. 
c) Political strategies relate to government policies and include lobbying, financial contributions to political parties, litigation, organized pressure strategies, and non-compliance strategies (Hillman and Hitt, 1999).

d) Socio-cultural strategies relate to social debates and public opinion and include framing strategies, public relations, advertising, and information campaigns (Lounsbury and Glynn, 2001).

\subsection{Destabilisation as multi-dimensional and enacted process}

Using TEF we propose a multi-dimensional perspective of destabilisation that integrates the four views discussed above. External pressures in the economic environment (first and second view) undermine the resource flows that sustain industries. Pressures in the socio-political environment (third view) can contribute to the de-legitimisation of industries, and weakening of political and public support. The response strategies discussed above are involved in the endogenous enactment of destabilisation (fourth view).

External pressures and endogenous enactment co-evolve with each other. Increasing external pressures weaken the performance of industries (both in terms of financial resources and socio-political legitimacy). Sustained performance problems leads actors to question the regime's viability, ultimately leading to weakening commitment and destabilisation. Destabilisation thus results from the increase of external pressures and from the weakening of actor commitment to established regimes. Weakening of commitment is a gradual process, which can be represented as a phase model (Weitzel and Jonsson, 1989; Collins, 2009). The enactment of destabilisation by industry actors can be described as following five phases, from denial to dissolution (Table 2).

This phase-model is an ideal-type that can be mobilised as a search heuristic for empirical analyses. When real-world cases deviate from the ideal-type, additional explanation is required. Recurring deviations may also give rise to differentiation of the ideal-type into a typology of different pathways.

\section{General outline of the two cases}

This section briefly describes two historical cases of the British coal industry and analyses the (mis)-match with the phasemodel. The first case concerns destabilisation in the transition

Table 2

A phase-model of destabilisation enactment.

(1) Blindness and denial

(2) Incremental responses to problems

(3) Increasing doubts and diversification

(4) Decline and destabilisation

(4a) Reorientation

(4b) Re-creation

(5) Dissolution
External pressures are initially weakly articulated. Industry actors initially deny performance problems or see them as temporary (e.g., due to recession). They downplay problems and follow a 'business as usual' mode, with strong regime commitment. External pressures become better articulated and linked to performance problems. Industry actors recognize the problems, but strategies remain defensive, focusing on tighter controls, incremental innovation strategies, and early diversification. Regime commitment remains strong.

Increasing pressures and problems create performance gaps, which lead industry actors to begin doubting the viability of (elements of) the existing regime. Industry actors begin exploring solutions outside the bounds of the existing regime. These diversification and exploration activities signal weakening commitment.

Problems turn into crises which raise the sense of urgency. Industry actors lose faith in the existing regime and implement drastic turnaround strategies. Depending on the severity of problems and the ability of industry actors to enact radical change, they can implement two types of change (Tushman and Romanelli, 1985):

Substantial change in some regime elements (technology, knowledge base, regulations) focusing on the development of new means for survival.

Deeper changes to core regime elements (mission, identity, core beliefs), focusing on the development of new hopes for survival around a fundamentally changed industry.

If these two types of change fail to address the mounting problems, actors lose faith and abandon the prospects for survival. Industries then try to make the most of decline: avoiding a full collapse and 'milking' the assets.

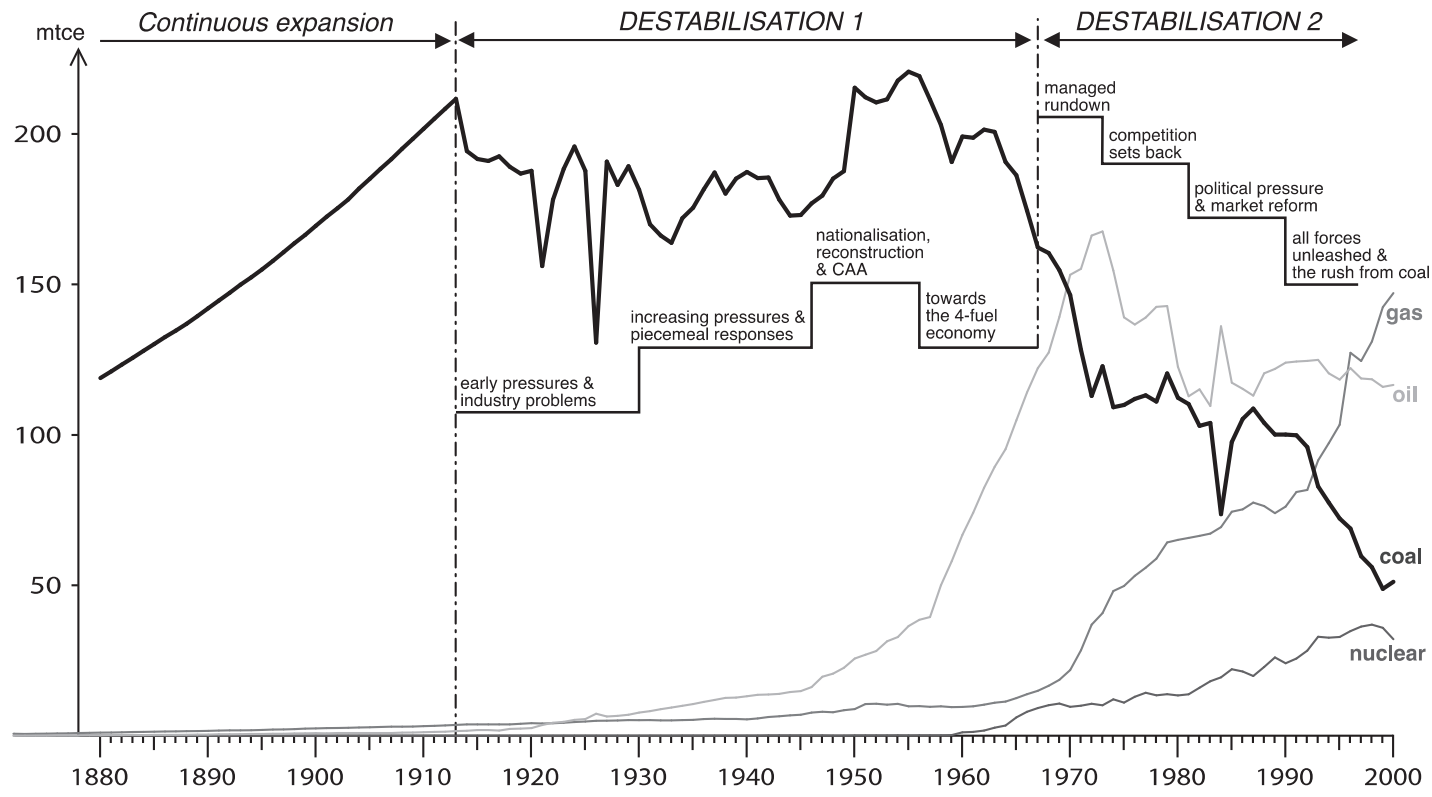

Fig. 3. British transition in primary energy sources and an outline of the destabilisation pattern for two historical cases. Source: (based on data from Fouquet and Pearson (1998):21). 
from coal dominance to the four-fuel economy (1913-1967). The second case is about the destabilisation of coal in the electricity sector (1967-1997). In both cases, destabilisation was related to economic, technological, political and cultural struggles. Both cases are schematically represented in Fig. 3, which provides a longitudinal overview of UK energy consumption. It shows continuous increase until 1913 followed by increasing turbulence in the inter-war period. The postwar decade saw new expansion (related to reconstruction), but also the rise of alternatives (first oil, later nuclear and gas).

Although the industry declined substantially since the late 1950s, it was able to re-invent itself and mobilise opportunities for continued survival in a smaller market segment (power generation). Coal sales to the electricity industry expanded until the early 1980s (see Fig. 9 below), while sales to other markets declined. Employment decreased rapidly after 1960 (Fig. 4), because of mine closures, mechanisation and rationalisation. This decline was halted by the 1973 oil crisis, but accelerated after Thatcher's election (1979). Employment continued to fall throughout the 1980s and decline accelerated after electricity industry privatization.

Sections 3.1 and 3.2 briefly describe both cases. Each discussion is organized in periods that address the most important economic and socio-political pressures and the responses from coal industry actors. The (mis)-match with the five-phase model is discussed at the end of each section.

Both descriptions draw on in-depth longitudinal case studies that can be found elsewhere (Turnheim and Geels, submitted for publication; Turnheim, 2012). These case studies draw on primary sources (shistorical newspaper articles, policy documents, annual reports from the National Coal Board, industry communications) and secondary sources about various aspects of the
British coal industry (Allen, 1970; Ashworth, 1986; Supple, 1987; Chapman, 1999; Beynon et al., 2000), smoke problems (Ashby and Anderson, 1981; Thorsheim, 2006), and acid rain problems (Boehmer-Christiansen and Skea, 1991).

\subsection{The destabilisation of the British coal industry (1913-1967)}

\subsubsection{3-1930: Early pressures and industry problems}

After World War I, British coal mining faced economic pressure from declining export markets due to competition from more efficient foreign new entrants (who adopted the latest mining technologies and methods). The productivity of North European mines increased rapidly (Fig. 5) in contrast to British, French and Belgian mines which lagged behind.

Economic pressure also came from domestic demand reduction (due to fuel efficiency improvements). The economic problems spilled over to the political environment leading to incidental subsidies and various government inquiries, which concluded that the large number of small mines should be amalgamated into larger, more efficient undertakings.

Anti-smoke organisations exerted normative pressures by redefining smoke as a dangerous killer, responsible for respiratory diseases, deaths and general pollution (Thorsheim, 2006). Public opinion and policy makers remained unconcerned, however.

The industry downplayed the structural causes for its economic problems, and did not respond with vigorous innovation strategies. Compared to other countries, the industry mechanised slowly. The percentage of mines with coal-cutting machines and pneumatic picks increased only gradually, from $8 \%$ in $1913,19 \%$ in 1924, to 42\% in 1933 (Allen, 1970). To improve competitiveness, mine owners cut wages, leading to labour unrest and major strikes (1921,

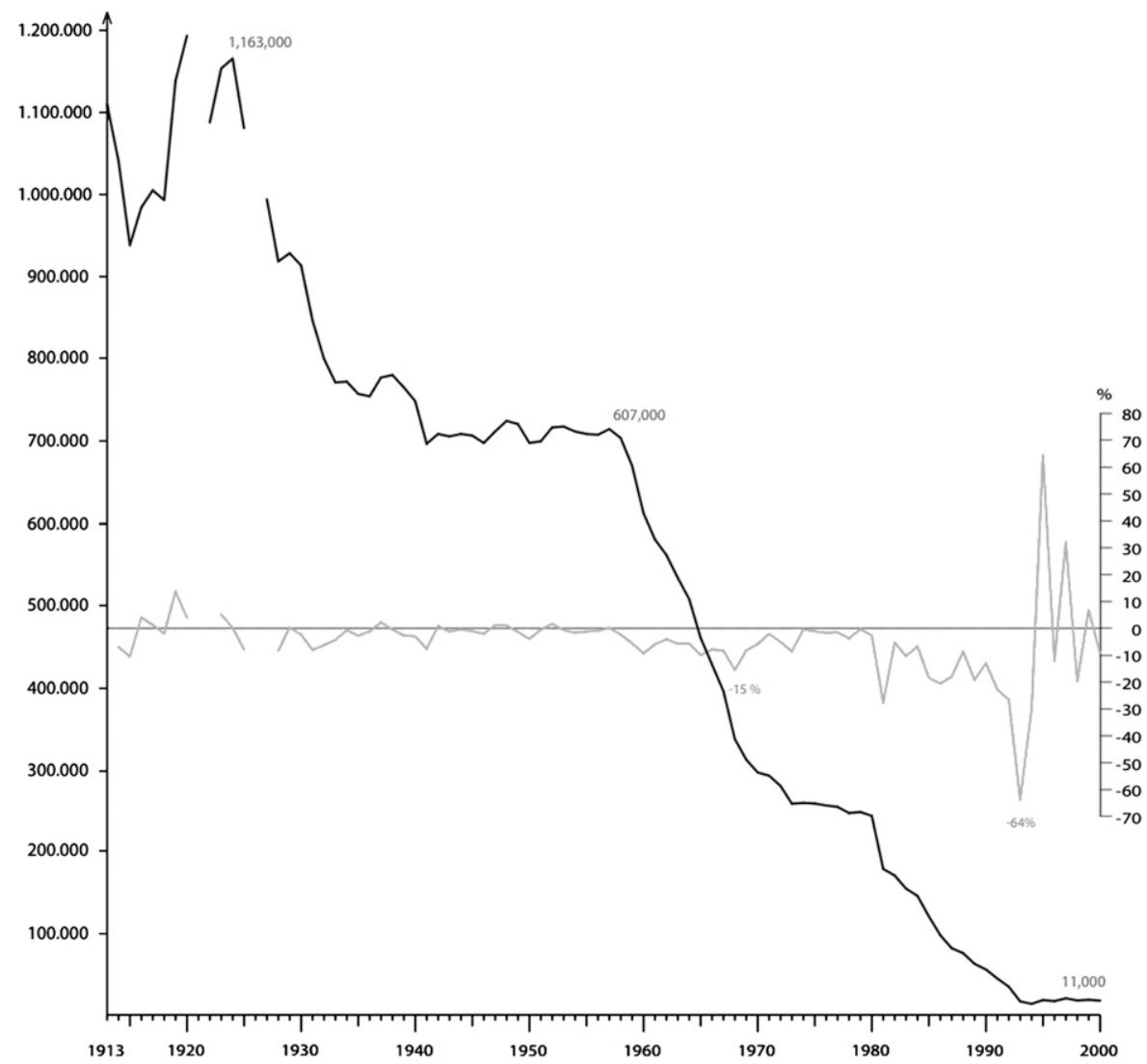

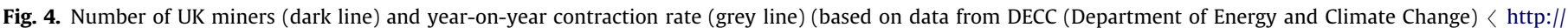
www.decc.gov.uk/en/content/cms/statistics/energy_stats/source/coal/coal.aspx >, (accessed 14-10-2009). 


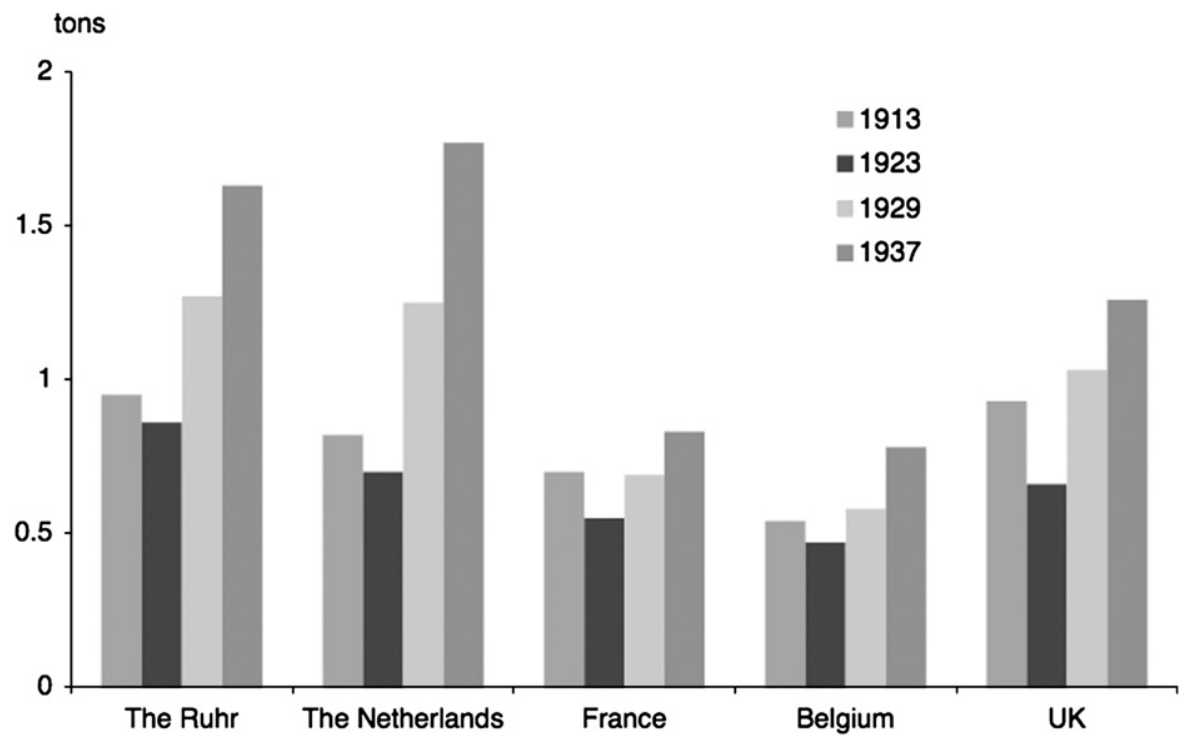

Fig. 5. Output per manshift (kg).

Source: (based on data from Scott (2006)).

1926). The recommendations from government inquiries (amalgamation) did not lead to targeted responses from the industry, which was characterised by limited coordination (Supple, 1987). The industry downplayed smoke problems, arguing that jobs and economic welfare were more important. Political strategies were used to lobby city councils, officials and judges to weaken smoke-regulations and apply these leniently (Thorsheim, 2006).

\subsubsection{0-1946: Increasing pressures and piecemeal responses}

In the 1930s, economic pressures came from domestic market contraction (due to the Great Depression) and further loss of export markets. There were many bankruptcies and coal came to be seen as a 'sick industry' (Supple, 1987). Employment figures plunged (Fig. 4). Concerns about unemployment and social problems ('too big to fail') led the government to step in and provide protection. The 1930 Coal Mines Act enabled the industry to become a cartel, which diminished competition by regulating output and prices, and thereby artificially stabilised the industry.

Although the wider public remained relatively unconcerned about smoke, broader cultural changes began to erode coal's legitimacy. These changes consisted of new visions of 'modern', 'clean', 'smokeless' and 'convenient' domestic life, propagated by the gas and electricity industries (Ashby and Anderson, 1981, see also Fig. 9 below). These visions resonated with broader cultural discourses. The smoke problem thus became part of a larger cultural 'package' that framed coal as old-fashioned, dirty, smoky and unhealthy.

The cartelised market reduced competitive incentives, and led the industry to focus on short-term survival and cost-reduction rather than on long-term innovation. The existing royalty structure, which led to the multiplication of leases for large mines, contributed further to reduce economic incentives for restructuration (Fine, 1990). Mechanisation proceeded in a piecemeal fashion and slower than abroad (Allen, 1970). Regarding smoke and cultural criticisms, the industry employed framing strategies. The chairman of the Coal Utilisation Council (CUC) argued that coal was a 'modern fuel' that could be burnt in "new-fashioned and highly efficient cookers" the industry had developed (The Times, 3 March, 1934). So, smoke-oriented innovation was mainly incremental, focusing on improved appliances that produced less smoke and burned coal more efficiently. Diversification to smokeless fuels (such as coke) remained limited.

\subsubsection{6-1956: Nationalisation, reconstruction and the London smog disaster}

Postwar reconstruction expanded the demand for coal, which was designated a 'strategic fuel'. In 1946, the government nationalised the coal industry for strategic reasons and because of accumulated frustration over the industry's inability to consolidate, rationalise and mechanise (Allen, 1970; Supple, 1987). Nationalisation stabilised the industry and employment (Fig. 4). Positive growth expectations underpinned the Plan for Coal (1950), which proposed long-term schemes for mechanisation and reorganisation. The National Coal Board ( $\mathrm{NCB}$ ) was granted an exclusive import license, providing protection from cheaper foreign coal. Technical alternatives created increasing pressure: heavy industries began to use more oil, while households used more gas and electricity (which both used coal as feedstock). In 1953, policymakers also announced plans for nuclear power.

Substantial pressure came from the socio-cultural environment: the Great London Smog (1952) disaster, which caused over 4000 excess deaths, caused public outrage that damaged coal's cultural legitimacy. It reinforced the public perception that coal was old-fashioned, dirty and outdated. The anti-smoke movement used the incident to increase pressure on politicians.

Newly expanding markets created optimism in the industry, and government support stimulated innovation. The Plan for Coal entailed $£ 635$ million of government investments for the introduction of power-loading, locomotive haulage, winding techniques, horizontal mining and training schemes for mining engineers (Allen, 1970). Slow implementation of the reconstruction agenda led to criticism, however. The industry also diversified into smokeless fuels, but did not invest in large-scale production capacity. Following the smog disaster, the industry recognised the need to address smoke problems, but defended the continuation of coal. It argued that the problem was not coal, but the incorrect use of coal in old appliances. The CUC therefore advocated new appliances and consumer education.

\subsubsection{6-1967: Technical alternatives, policy change and loss of faith}

In this period, many substantial pressures aligned. First, public outrage and movement pressure led to the Clean Air Act (1956), which restricted coal use in people's homes and enabled cities to 
create smokeless areas. By 1970, the number of premises covered by smoke control orders had grown to 4.5 million (Fig. 6). Smoke emissions rapidly declined, also because of household switchovers to gas.

Second, competition from other fuels caused overall coal demand to decline (Fig. 3): petroleum use tripled between 1960 and 1973; nuclear power came online in 1959, supported by high hopes and promises of nuclear utopias (Williams, 1980); and

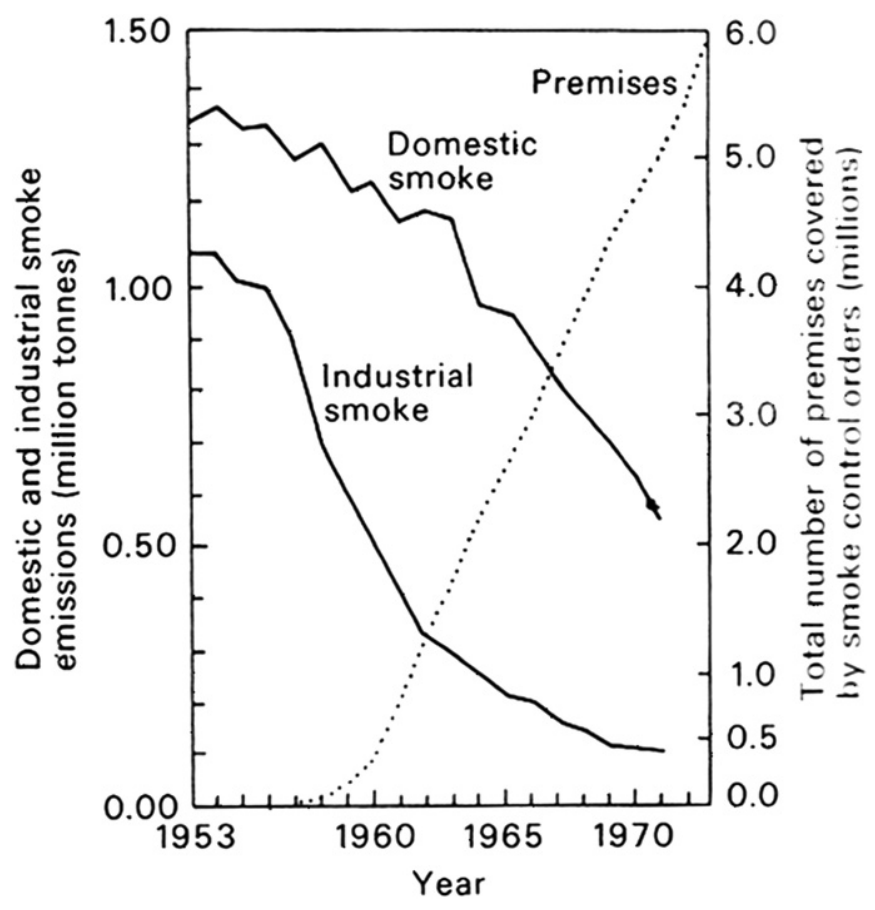

Fig. 6. Domestic and industrial smoke emissions (1953-1973). Source: (Ashby and Anderson, 1981:118). natural gas, discovered in the North Sea in the mid-1960s, began to replace coal gas. Declining coal markets caused financial losses in the industry (Fig. 7). The only remaining growth market was electricity generation. But in this market, coal faced growing governmental enthusiasm for the nuclear option, backed by optimistic cost estimates (Williams, 1980). Coal also faced pressure from the government's desire to replace coal-fired with oil-fired stations (Hannah, 1982:169-173).

Third, policy makers downscaled support for the coal industry. Macro-economic concerns over government spending, frustrations over the industry's slow pace of modernisation and escalating costs (Ashworth, 1986), and positive expectations about nuclear energy led policy makers to adopt a coal policy of 'controlled rundown'. The Revised Plan for Coal (1959) increased the rate of pit closures and focused investments on fewer mines. The 1965 White Paper on Fuel Policy envisaged a shift towards a four-fuel economy, with decreasing shares for coal, and increasing shares for alternatives. The removal of protective measures (oil tax, contracts for electricity industry and heating establishments) enhanced competition from alternative fuels, which caused decline and destabilisation. Politically secured contracts for electricity generation formed the industry's lifeline, which prevented complete dissolution.

In 1957 and 1958 the industry perceived sales declines as temporary setbacks. But in 1959, it recognised the seriousness of the challenge: "Competition with oil has become intense in recent years, and it has been necessary for the industry and the coal distributive trade to adapt themselves to a competitive market" (NCB annual report, 1959:9). The Revised Plan for Coal (1959) accelerated mine modernisation by addressing the layout of mines, improving tunnelling methods, and enhancing the use of power-loaders (Allen, 1970). Output per manshift improved substantially, from $1.25 \mathrm{t}$ in 1957, to $1.56 \mathrm{t}$ in 1962 and $2.1 \mathrm{t}$ in 1968 (Allen, 1970). The industry also further developed (secondgeneration) smokeless fuels and worked with appliance manufacturers to improve domestic stoves and central heating systems (Ashworth, 1986). The industry also interacted closer with consumers, whom it had long taken for granted. Overall, the industry

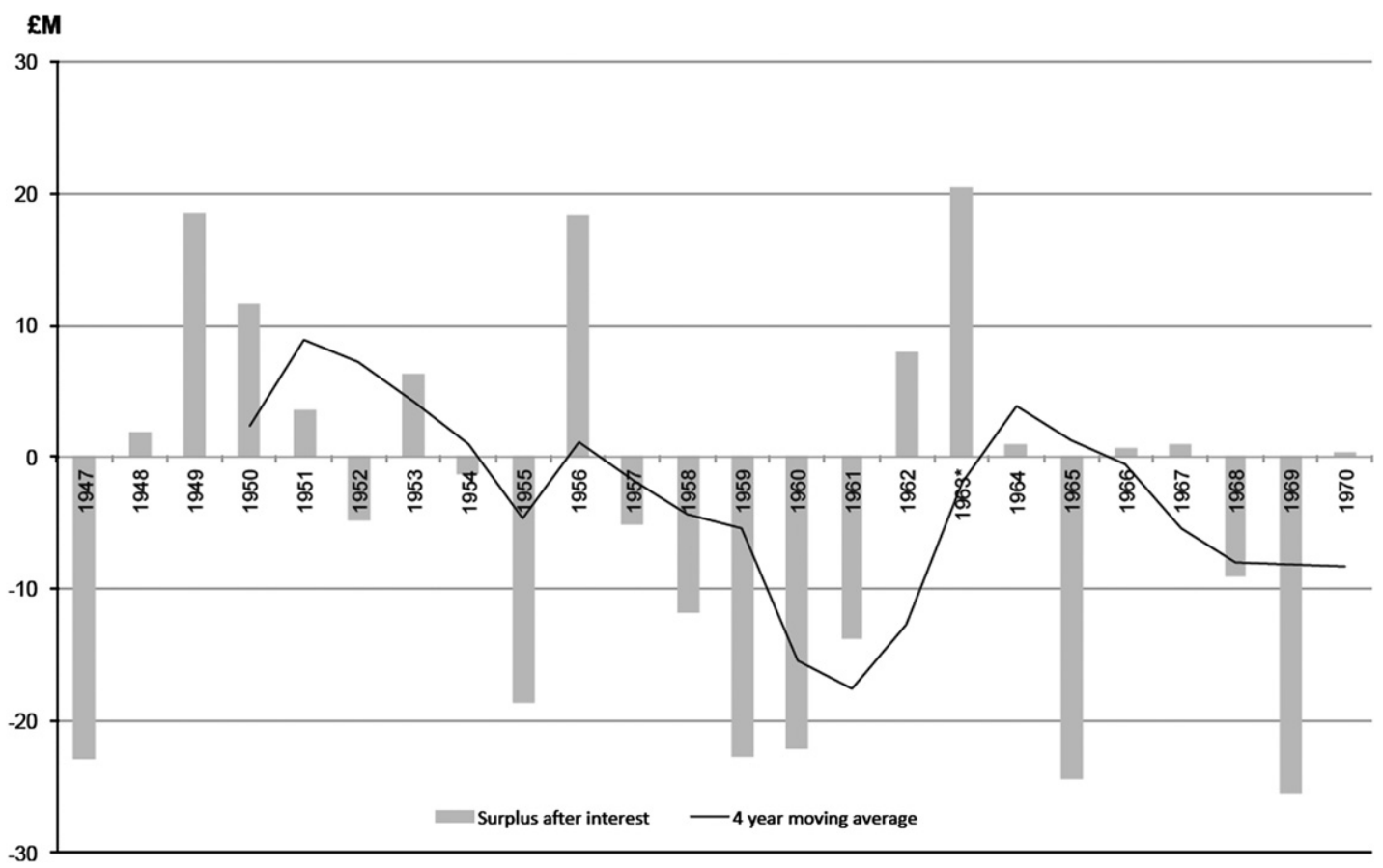

Fig. 7. Surplus after interest payment ( $\mathrm{m}$, nominal value) (compiled from NCB annual reports). 


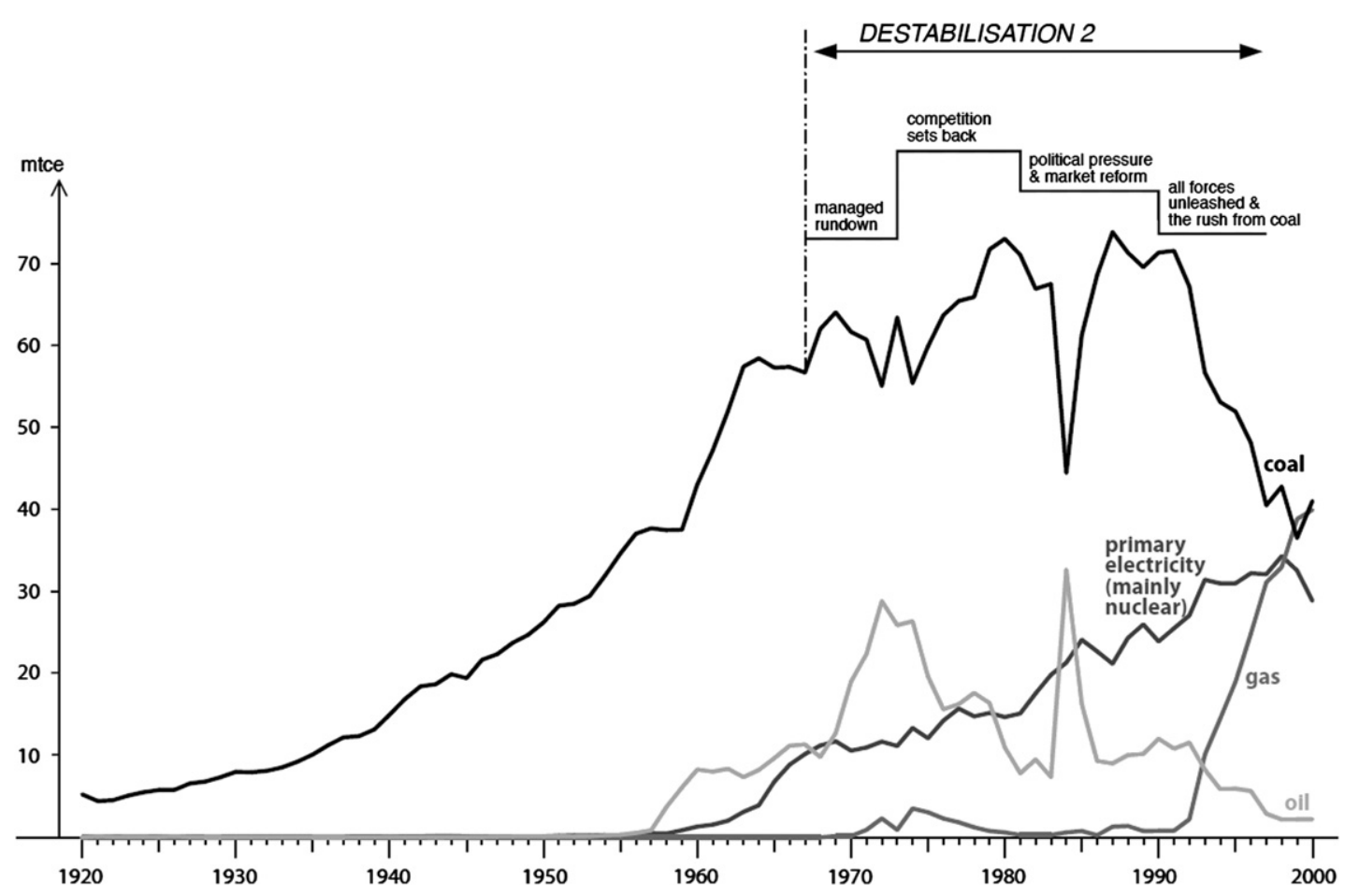

Fig. 8. Coal consumption by the power sector.

Source: (based on data from: Department of Energy and Climate Change; www.decc.gov.uk).

attempted a major transformation in mining technology, products and knowledge base. The 1965 White Paper was a major shock, because its annual coal market estimate (170-180 million tons) was much lower than the 1959 Revised Plan estimate (206 million tons). The White Paper "led to a loss of confidence within the industry" (NCB annual report, 1965:xi), and forced it to accept a reduced role in fuel supply and a change in mission (to become the supplier of the electricity industry).

\subsection{5. (Mis)match with phase model}

The first two periods fit well with the model, with the industry first downplaying structural problems and then introducing piecemeal and incremental innovations. The third period deviates from the model, because expanding post-war markets created optimism instead of increasing doubts. The industry innovated and modernized to meet the new opportunities, not because of despair. It also diversified (somewhat) into smokeless fuels to address the smoke problem, which caused some concern for the industry. The fourth period deviates from the model, because it encompasses both the fourth and fifth phase. The reason was that the industry followed two tracks. There was decline (fifth model phase) in many market segments, which caused major performance problems (financial problems, loss of cultural legitimacy and political support). But there was also strategic recreation (fourth phase) towards the growing electricity market, which sets the stage for the second case.

\subsection{The destabilisation and decline of the British deep coal mining (1967-1997)}

\subsubsection{7-1973: Managed rundown, removal of support structures} and exposure to market forces

The 1965 White Paper resulted in accelerated mine closures and shifts in relative investments from coal to nuclear power, which policymakers perceived as a promising new energy source (Beynon et al., 2000). The closures caused discontent with miners.
In the socio-political environment, acid rain emerged as an international issue. Concern in the UK remained limited, however.

The NCB implemented major pit closure programmes, which reduced employment from 455,000 miners in 1965 to 252,000 in 1973 (Fig. 4). The industry survived by focusing on the electricity market, which used increasing amounts of coal (Fig. 8). The NCB secured politically negotiated long-term contracts with the CEGB (Central Electricity Generating Board). The CEGB was not happy with this 'forced marriage' and considered itself a "captive purchaser of a single or largely preponderant basic fuel" (CEGB annual Report 1970-1971).

\subsubsection{3-1981: Revival, new hopes and investments}

The 1973 the oil crisis was an extreme event that fundamentally redefined the position of coal in the economic environment. It weakened the competitive position of oil and revitalised political (and financial) support for coal, which regained strategic and symbolic relevance. The oil shock also triggered large transnational corporations to become more involved in an expanding international coal regime (Beynon et al., 2000). The increasing availability of cheap international coal increased the dissatisfaction of the electricity industry (which was forced to buy more expensive British coal). Pressure also came from miners, who took advantage of the energy crisis to formulate wage claims in 1973. Escalating negotiations culminated in strikes and a major political crisis that brought down Heath's conservative government (Chapman, 1999). Pressure from the international acid rain debate was deflected by British policy makers who justified inaction by highlighting scientific uncertainties and economic costs (Boehmer-Christiansen and Skea, 1991).

The oil crisis created optimism in the coal industry, which secured medium-term stabilising commitments in the Plan for Coal (1974). The pace of decline was halted (Beynon et al., 2000). New capital investment improved mining performance and stimulated innovation (e.g., remote controlled mining, new deep mining complexes such as the Selby 'superpit', some diversification in improved coal combustion). Using framing strategies, the 
Table 3

Provenance of coal used and stocked in the UK in mtons and percentages of total coal. Source: (Data: DECC, www.decc.org.uk).

\begin{tabular}{ccccccc}
\hline & \multicolumn{2}{c}{ Deepmined output } & \multicolumn{2}{c}{ Opencast output } & \multicolumn{2}{c}{ Coal imports } \\
\hline 1967 & 167.7 & $(94.4 \%)$ & 9.9 & $(5.6 \%)$ & 0.0 & $(0.0 \%)$ \\
1972 & 109.1 & $(82.7 \%)$ & 17.7 & $(13.5 \%)$ & 5.0 & $(3.8 \%)$ \\
1977 & 107.1 & $(86.0 \%)$ & 15.0 & $(12.1 \%)$ & 2.4 & $(2.0 \%)$ \\
1982 & 106.2 & $(82.4 \%)$ & 18.6 & $(14.4 \%)$ & 4.1 & $(3.2 \%)$ \\
1987 & 86.0 & $(75.2 \%)$ & 18.6 & $(16.2 \%)$ & 9.8 & $(8.6 \%)$ \\
1992 & 65.8 & $(62.8 \%)$ & 18.7 & $(17.8 \%)$ & 20.3 & $(19.4 \%)$ \\
1997 & 30.3 & $(44.4 \%)$ & 18.2 & $(26.7 \%)$ & 19.8 & $(28.9 \%)$ \\
\hline
\end{tabular}

NCB constructed glorious images of a re-born industry. But the positive outlook masked accumulated tensions such as (a) increasing dissatisfaction by the CEGB, (b) the rise of an international coal regime (which was kept at bay through import restrictions), and (c) internal disagreement about the industry's mission (social mission vs. competitiveness) and strategy (restructuring vs. maximising capacity).

\subsubsection{1-1990: Political pressure for market reform and regime transformation}

Thatcher's 1979 election introduced a new and pervasive market ideology in the government. Liberalisation and market reform were seen as appropriate solutions for many industries. Mining was discursively framed as a 'sick' industry, which had to modernize and become profitable (Chapman, 1999). Policymakers intended to 'turn the coal industry into a business', and thus (definitively) break with the inherited logic of public interest monopoly. Cheap international coal put significant price pressure on the NCB. International price benchmarks were increasingly used as performance comparator for British coal. The electricity industry expressed dissatisfactions with its captive customer position and was allowed to gradually increase coal imports (Table 3 ). The use of deep-mined coal gradually began to decline.

Policymakers limited financial support and made it conditional on the industry's deep restructuring. The tensions between government and labour unions escalated, resulting in the Great Miners' Strike (1984-1985), which was crushed in a heavily politicised context. The debate over the fate of 'uneconomic pits' was thus resolved by force in favour of radical restructuring. Subsequently, the government dismantled support structures and downsized innovation programs. The 1986 oil price collapse was another blow for the competitiveness and strategic importance of the industry.

Various environmental organisations mobilised around acid rain and challenged the government's inactive position. Their political influence was limited, however, and the government successfully shielded the electricity and coal industries from this pressure (Boehmer-Christiansen and Skea, 1991).

Under heavy political pressure, the coal industry downsized and restructured. From the mid-1980s market and organisational reforms became oriented towards privatisation. The NCB's New Strategy for Coal (1985) therefore had two main goals: (1) phase out the industry's dependence on subsidies, and (2) sell coal at internationally competitive prices. Thatcher installed a new NCB chairman (MacGregor), who imposed a new managerial style that was driven by financial targets and geared towards competitiveness (Beynon et al., 2000). He accelerated mine closures without concern for social implications and mining communities. The industry was re-branded 'British Coal' (BC) in 1986 to symbolise a new era.

\subsubsection{0-1997: All forces unleashed and the rush from coal}

The privatisation of the electricity supply industry (1990) caused major changes in the economic environment of the coal industry. This policy change broke the electricity supply industry's (ESI) regulated dependence on UK coal, and led to significant increases in foreign coal imports( Table 3). BC also faced economic pressure from technical alternatives such as Combined Cycle Gas Turbines (CCGT). By 1997, electricity companies had constructed $13 \mathrm{GW}$ of gas-fired capacity (with 5-6 GW under construction), which accounted for $30 \%$ of electricity generated in England and Wales (Chapman, 1999). This 'dash for gas' displaced the equivalent of 50 million tonnes of coal (Fig. 8). With gas reducing UK sulphur emissions, the government was willing to acknowledge the acid rain problem, claiming that it was taking decisive action to address the problem (Boehmer-Christiansen and Skea, 1991). ESI privatisation unleashed the forces of new technology and foreign coal, and caused a collapse of markets for BC.

The coal industry had warned that ESI privatisation would undermine the intended privatisation of British Coal policy. These warnings had little effect, and subsequent pleas for protection were also unsuccessful. The industry underwent extreme contraction and employment fell from 49,000 to 10,000 miners between 1990 and 1996 (Fig. 4). It was hastily privatised in 1994, which was "a messy and unsatisfactory affair, a product of external forces and expediency" (Beynon et al., 2000:9). In subsequent years, deep-mining was further displaced by opencast mining and imports.

\subsection{5. (Mis)match with phase model}

The first periods fits well with the model, with the industry clinging on to an expanding market (power generation) and restructuring to match the new situation. The second period deviates from the model because the oil crisis created new enthusiasm and positive expectations. The third period partially matches the model. Increasing pressures (negative government attitude and policies, competition from nuclear and gas, price threats from foreign coal) caused doubts in the industry about future viability. But the industry did not diversify and explore alternative paths, because the government imposed management that shrunk the industry and cut innovation programs. Industry strategy was increasingly reduced to 'fire-fighting' and short-term responses to imminent threats ('living in a permanent crisis'). The fourth period deviates from the model in the sense that the destabilisation process skipped the fourth phase (reorientation) and immediately moved to the fifth phase (dissolution). Reorientation was difficult because government policies had eroded slack and (financial and technical) capabilities. The industry therefore had limited possibility to respond to the unleashed competition that followed ESI privatisation. Collapsing markets forced the rapid shrinking of the industry.

So, for both case studies, the five-phase model of destabilisation had similarities to the empirical periods, but also deviations. These deviations were due to macro-economic changes (post-war reconstruction in the 1950 s and oil crisis in the 1970s) and limitations on the scope for strategic action (particularly since the late 1980s). The deviations underline that the phase-model should be flexibly used as a heuristic ideal-type, not as a mould into which historical data are to be forced.

\section{Specific lessons from the historical cases}

This section uses the two cases to articulate specific lessons regarding the overall phenomenon (4.1) and specific dimensions from economic and socio-political environments (4.2). 


\subsection{Lessons about the overall destabilisation phenomenon}

\subsubsection{Economic drivers mediated by socio-political influences}

In terms of the triple embeddedness framework, both cases suggest that pressures in the economic environment were the direct causes of destabilisation, and that pressures in the sociopolitical environment were mediating factors.

In the first case, crucial destabilising pressures came from: new entrants in export markets (1920s-1930s), changing user preferences (1950s-1960s), technological competition (1950s1960s), and shrinking markets (1950s-1960s). These pressures undermined the financial performance of the coal industry. Policy makers propped up the industry in the 1930s and 1950s. Decreasing legitimacy eroded this support in the late 1950s, and enhanced the vulnerability of the coal industry to economic pressures after the 1965 White Paper.

In the second case, core economic pressures came from cheap international coal, nuclear power and gas. These pressures were mediated and unleashed by neo-liberal Conservative policies in the 1980 s and early 1990 s.

This finding about the relative importance of economic and socio-political environments resonates with Levy and Newell (2000: 9) who conclude, in a review of business responses to environmental issues, that economic considerations have the greatest influence on corporate strategy: "Economic, political and cultural forces interact in complex ways to produce the outcomes on each of the issues. Overall, however, the evidence indicates that the economic opportunities and threats presented by each issue constitute the main drivers of business responses. Cultural and political factors play a secondary role, influencing how business perceives its economic interests and helping to shape the specific tactics that businesses adopt". While this conclusion seems plausible, we suggest that more in-depth studies are needed to establish its general validity.

\subsubsection{The seeds for destabilisation are sown long before they take effect}

Many external pressures take decades to accumulate and exert their full influence. This gradual increase may hinder timely recognition by industry actors. ${ }^{2}$

In the first case, electricity and (coal) gas took decades to enter households, progressing gradually through various niche applications (lighting, cooking, heating), before they replaced the direct use of coal in the 1950s. In the early 1950s, the coal industry did not yet perceive alternative fuels (gas, electricity, oil) as threats, but as allies in temporarily addressing fuel shortages: "maximum use must be made of other fuels to fill the gap" (NCB Annual Report, 1954:27). Socio-cultural pressures around smoke also took decades to build up, starting in the 1880 s, gathering pace in the 1930s, and escalating after the 1952 Smog disaster. The industry downplayed smoke problems and was not well prepared when smoke policies changed the selection environment.

The second case contains several instances of gradually increasing pressures. First, pressure from international coal was building since the 1960s. This pressure was kept at bay until the mid-1980s (via import restrictions), but exerted its full force when protective barriers were removed in 1990. Second, tensions between the coal industry and electricity supply industry (ESI) exacerbated gradually during the 1970s and 1980s. The coal industry appears to have underestimated this worsening relationship, which became an important source of destabilisation in the 1990s (when ESI actors increased the proportion of imports and

\footnotetext{
${ }^{2}$ This is reminiscent to the popular parable of the frog in the slowly heating pan.
}

rushed from coal to gas). Third, neo-liberal policies were the outcome of longer-term processes. In the late 1950s, policymakers already became frustrated about the slow pace and escalating costs of the industry's modernisation. Dissatisfaction with underperforming nationalised industries grew in the $1960 \mathrm{~s}$ and 1970s. Tensions between the industry's social objectives and its economic performance became a source of division (a) between the NCB/BC and the government, ${ }^{3}$ and (b) between the miners and industry management. ${ }^{4}$ The instalment of a new Conservative ideology and discourse, implemented during the 1980s and 1990s, imposed a clear new direction for the industry, cutting across these accumulated tensions and debates in a highly politicised process.

\subsubsection{Interactions and alignments of pressures in destabilisation}

Destabilisation of existing industries becomes more likely when external pressures spill over between environments and align with each other. While industry actors tend to be relatively good at addressing one-dimensional pressures, such (unexpected) alignments may catch them off guard and overwhelm them. In both cases, full destabilisation involved the simultaneous articulation and alignment of multiple pressures.

In the first case, we identify a 'perfect storm' pattern, in which multiple pressures increased and overwhelmed the coal industry between 1956 and 1965: competition from technical alternatives, negative cultural discourse about coal, the Clean Air Act (CAA, 1956), and the downscaling of government support.

In the second case, the crucial alignment was between competitive pressures (cheap foreign coal, gas, nuclear power) and a macro-level ('landscape') political ideology (neo-liberalism), which was translated into radical policy reforms, causing a coal market collapse.

\subsubsection{The role of shocks and extreme events}

Destabilisation can be accelerated or halted by shocks and extreme events. The effect of extreme events is mediated by contexts and preceding articulation processes.

- Crises can raise the sense of urgency regarding problems, and increase public and political pressure. The London Smog (1952), for example, caused public outrage and led to the CAA (1956). But smog events with many casualties had happened in previous decades without similar effects (Thorsheim, 2006). So, public outrage in the 1950s was not only due to the smog event, but also to the delegitimisation of coal in preceding decades (through smoke activism, a cultural discourse of cleanliness and health, and new visions of the household).

- Radical policy reform may accelerate destabilisation, when policies substantially change economic frame conditions and provide long-term signals (which, in turn, affect beliefs and technology investments). The 1965 White Paper and 1990 electricity market reform were crucial events in both destabilisation cases. Radical policies are often preceded by longstanding debates and the accumulation of tensions (see lesson 2 in Section 4.2).

- Macro-economic events affect industry destabilisation by influencing market demand, competitive positions and/or future expectations. The Great Depression decreased markets for coal,

\footnotetext{
${ }^{3}$ An important tension concerned levels of cross-subsidy between profitable mines and loss-making collieries (we want to thank one of the reviewers for pointing this out; see also Parker, 2000).

${ }^{4}$ An important tension concerned the speed of productivity improvements, closures and layoffs, which influenced the miner's willingness to strike (we want to thank one of the reviewers for pointing this out; see also Parker, 2000).
} 
Table 4

Summary of destabilisation paths in both cases.

\begin{tabular}{|c|c|c|}
\hline & Case 1 & Case 2 \\
\hline Destabilisation context & $\begin{array}{l}\text { Gradual accumulation of pressures } \\
\text { Perfect storm } \\
\text { Multiple markets shrink }\end{array}$ & $\begin{array}{l}\text { Landscape stress } \\
\text { Radical environmental change (market reforms) } \\
\text { Market collapse }\end{array}$ \\
\hline Main pressures & $\begin{array}{l}\text { New entrants } \\
\text { Technological competition } \\
\text { Normative problem (smoke) }\end{array}$ & $\begin{array}{l}\text { Market reduction } \\
\text { Supply-side neglect } \\
\text { Customer dissatisfaction } \\
\text { Political pressure (market ideology, liberalisation) } \\
\text { Technological alternatives }\end{array}$ \\
\hline Enactment pattern & $\begin{array}{l}\text { Too little, too late } \\
\text { Re-orientation but greatly reduced size }\end{array}$ & $\begin{array}{l}\text { Partial adaptation to short-term pressures } \\
\text { Neglect of landscape stress } \\
\text { Near-terminal contraction }\end{array}$ \\
\hline
\end{tabular}

causing economic problems. The Second World War shifted coal use to the war industry, whereas post-war reconstruction created booming markets and new enthusiasm. The 1973 oil crisis also created new enthusiasm, because it positively influenced the competitive position of coal compared to oil. In the 1950s and 1970s, coal industry actors seized the new opportunities and articulated new promises about a bright future. This new enthusiasm may, however, have led industry actors to pay insufficient attention to deeper structural problems, which came back with a vengeance when macroeconomic pressures changed again (inflation and budgetary problems in late 1950s, and oil price collapse after 1986).

\subsubsection{Different destabilisation pathways}

Destabilisation processes can follow different pathways, depending on the interactions between external pressures and endogenous responses. Table 4 provides a summary of both cases, with the 'destabilisation context' characterizing the overall pattern.

\subsection{Lessons related to specific dimensions of triple embeddedness framework}

\subsubsection{Limited direct effects from social movement pressures}

In both cases, social movements exerted pressures relating to environmental problems (smoke, acid rain). The direct effects on destabilisation long remained limited, because policy makers shielded the industry, because public opinion was limitedly concerned (in the first case), and because industries used political and framing strategies to defend themselves.

In the first case, anti-smoke movements emerged in the $1880 \mathrm{~s}$ The first two decades, these movements aimed to educate the public about the dangers of coal smoke (via public lectures, exhibitions, brochures, booklets). These efforts had limited effect, because public opinion continued to associate smoking chimneys with jobs and economic prosperity. By 1900 activists began widening their attention to greater enforcement of existing smoke laws (Thorsheim, 2006). In the 1910s and 1920s, the movement was joined by professional groups such as doctors, chemists, architects and engineers, who paid more attention to technological solutions and fuel efficiency (e.g., better boiler and furnace designs). The electricity and gas industry also joined the anti-smoke movement, using smokelessness as a marketing strategy for their products (see Fig. 9 for an advert for coal gas).

Public opinion long remained unconcerned. In 1921, an editorial in The Times ( 23 August) commented that "We are still far from the point at which compulsion [of domestic smoke curbing] is possible. Public opinion has to be educated" (cited in

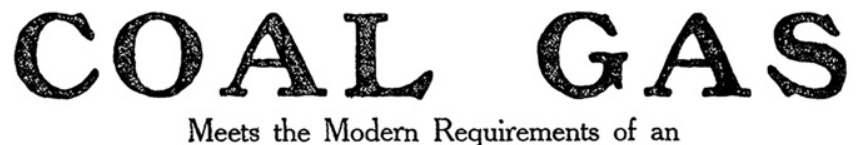

\section{Efficient, Clean, Convenient,} Economical, Smokeless Fuel.

AT HOME

THE GAS COOKER

GAS FIRES

GAS WATER HEATERS

Gas Lighting aids ventilation and preve
eye-strain;
is always ready and reliable;
save disagreeable house-work, and are in
pensable in the sick-room;
give hot water at any time.
L L - G $\mathbf{A}$ S $\mathbf{S} \mathbf{S} \mathbf{S}$
the Servant Problem and makes possible
AIR IN A CLEAN CITY.

COAL GAS for Power and Industrial Purposes means Minimum Floor Space; Prevention of Smoke Nuisance; Saving in Labour; Intense, Concentrated Heat; Economical Production. With gas, heat can be instantly obtained and as quickly dispensed with.

When Solid Fuel is required for Kitchen Ranges, for Central Heating, for Greenhouses

\section{Gas Coke is not only a Smokeless Fuel; it is the Cheapest Solid Fuel.}

For Factories, for Schools, for Public Buildings.

Information will be readily sent on application toTHE BRITISH COMMERCIAL GAS ASSOCIATION, 47, VICTORIA STREET, WESTMINSTER, S.W.

Fig. 9. Advert by British commercial gas association (The Times, 28-1-1914).

Thorsheim, 2006:52). The Newton Committee Report (1921) signalled national policy recognition of smoke problems, but the subsequent Public Health (Smoke Abatement) Act (1926) was relatively weak (Ashby and Anderson, 1981). More influential was the alignment of smoke with new visions of domestic life, which in the 1930s culminated in a cultural discourse that framed coal as old-fashioned, dirty, smoky and unhealthy. This discourse formed the context in which the 1952 Smog disaster could have major effects, culminating in the CAA (1956). So, it took a long time for smoke problems to influence the destabilisation process, and when it did, this influence was due to alignments with broader cultural trends and a major shock. 
In the second case, environmental activists tried to get acid rain on the political agenda. But their efforts were diverted by policy makers and lobbyists from electricity and coal industries, who succeeded in keeping the issue off the agenda until the late 1980s (Boehmer-Christiansen and Skea, 1991). The problem was only allowed onto the agenda when it could be linked to a solution (gas) that the market favored anyway. So, environmental concerns did not really participate in the destabilisation process.

\subsubsection{The importance of changing policy support and reasons for policy change}

Major policy change is often important in destabilisation, because it shapes both the direct support for industries (e.g., subsidies) and economic frame conditions (taxes, import restrictions, regulations).

In the 1930s, the government propped up the coal industry via a cartel arrangement and in 1946 it nationalised the industry. Subsequently, policymakers became more frustrated with the industry and more enthusiastic about alternatives, which were supported via the new fuel policy of 1965 , which institutionalised the transition to a four-fuel economy.

In the second case, policymakers supported the coal industry in the 1970s, effectively halting the destabilisation process. But in the 1980s and 1990s, dissatisfaction with the industry and macropolitical ideologies resulted in structural reforms that collapsed coal markets.

So, both cases show that policymakers can provide crucial support in difficult times. However, this support rarely lasts forever, and loss of support can have serious consequences. The second case also shows that ideology and political determination can lead to structural reforms. The cases also show that major policy change tends to emerge from alignments between multiple processes. The CAA (1956), for example, could be introduced because technical alternatives (such as solid smokeless fuels and modified stoves and fireplaces) had become economically feasible, and because of pressure from public opinion. And the 1965 White Paper can be seen as the outcome of: (a) accumulated political frustration about the coal industry's slow modernisation and continued need for subsidies, (b) enthusiasm about alternatives (nuclear power), (c) coal's decreasing economic importance and political clout (in terms of jobs, GDP contributions, union power), d) eroded cultural legitimacy (coal is 'outdated' and 'old-fashioned'). Such alignments of processes create a context in which policy makers can introduce major policy change, and thereby also provide a form of solution to accumulated tensions.

\subsubsection{The role of public opinion and discourse}

Public opinion and discourse is important, because it, first, influences the cultural legitimacy of industries. In the 1930s, the public legitimacy of coal weakened, because of negative public framings. The legitimacy of the coal industry was still high, however, because of its social and economic significance. Secondly, public discourse shapes cultural enthusiasm about new technologies. In the 1930s, new cultural repertoires and visions of the household created enthusiasm about electricity and gas. In the 1950s and 1960s, positive visions about nuclear power created (political) enthusiasm for this technology. Thirdly, public discourse mediates the effectiveness of social movements. Smoke activists were limitedly influential until they linked up with cultural repertoires of cleanliness and modernity (1930s) and until the Smog disaster created public outrage. Fourth, public opinion shapes the feasibility of policy reform. Political support in the 1930s and nationalisation (1946) was possible, because it was backed by positive views of the coal industry. The introduction of the 1956 CAA was deemed feasible because of public support. In
1955, an internal Cabinet memorandum assessed that "public opinion is ready for a strong government lead and would support measures on the scale proposed" (cited in Thorsheim, 2006:181). In the 1980s, Thatcher accompanied her (authoritarian) reforms of the industry with a deliberately crafted political discourse (incorporating themes such as the need for self-sufficient industries, coal industry being too dependent on subsidies, miners as 'the enemy within'), which addressed existing tensions.

\subsubsection{Bi-directional causality between technological alternatives and destabilisation}

The causal relationship between technological novelty and destabilisation is bi-directional: technical alternatives contribute to regime destabilisation, while regime problems create 'windows of opportunity' for the diffusion of new technologies (Turnheim and Geels, submitted for publication).

In the first case, technical alternatives created market pressure on coal in various markets: coal gas and electricity competed with coal in households; fuel oil and diesel competed with coal in railways, heavy industries, and electricity generation; nuclear and gas were serious competitors in power generation. The alternatives also reinforced other destabilisation pressures such as the anti-smoke movement, new visions and consumer preferences and weakening policy support for coal. The availability of credible alternatives also enabled the introduction of the 1956 CAA. On the other hand, regime problems created opportunities for alternatives: smoke problems allowed gas and electricity to portray themselves as smokeless solutions; smoke problems led to the 1956 CAA, which changed the selection environment in favor of alternatives; postwar coal supply shortages created market opportunities for alternatives.

In the second case, oil, nuclear and natural gas disrupted markets for coal. Political enthusiasm about alternatives also weakened their willingness to support coal. On the other hand, coal industry destabilisation provided opportunities for alternatives. Political frustrations with coal meant that policy makers were eager to support alternatives. The framing of the coal industry as 'outdated' and 'old-fashioned' heightened the contrast with 'modern' industries (such as nuclear). The 1990 electricity market reforms provided the opportunities for the 'dash for gas'.

Both cases show that the bi-directional causality between novelty and industry destabilisation is not only played out in markets, but also on political and socio-cultural dimensions.

\subsubsection{Industry regimes and inertia}

Industry actors are usually committed to the elements of industry regimes (technical knowledge base, core beliefs, mission, industry-specific regulations), which are stabilized by various lock-in mechanisms (Section 2.2). This commitment creates inertia and resistance to change, which may hinder timely adjustment to external pressures or lead to the underestimation of threats.

In the first case, the industry long adhered to the core belief that Britain was built on coal in the past and would remain so in the future. Even in the early 1950s, the dominant belief was that coal would remain the primary fuel and that alternatives could temporarily fill supply gaps in particular market segments. The core belief thus led the industry to underestimate the threat from alternatives and ignore structural problems (slow mechanisation, low productivity, weak international competitiveness). This core belief was linked to the industry's mission. The industry perceived itself as a supply-side industry that would always have many markets and therefore could be relatively unconcerned about specific consumers. The core belief was also reinforced by regulations that created a protective cartel (1930 Coal Mines Act) and 
guaranteed government support (1946 nationalisation). The cartel diminished the incentive to mechanise and rationalise. And the Plan for Coal (1950) lacked urgency in its implementation. As a result, the industry was relatively slow (compared to other countries) in moving from existing technical competencies (labourintensive, craft-based) to new ones. It was not until the early 1960s that the industry recreated itself and changed core regime elements: it reoriented its technical base (mechanization, rationalization, science-based), it accepted its diminished relative position, and it focused its mission towards the electricity supply industry (ESI). But this recreation was a crash program that can be characterised as 'too little, too late'.

In the second case, the industry believed that its perceived mission (preferred supplier of ESI) would provide long-term stability, partly because it was supported by politically-negotiated contracts. The optimism of the 1970s renewed the belief that coal was a strategic fuel. Positive expectations underpinned new technical achievements (remote-controlled mining, new deepmining complexes). But these beliefs and commitment may have led industry actors to downplay tensions and threats (cheap foreign coal, dissatisfaction from ESI, political frustration with nationalised industries, emergence of neo-liberal ideas). The relative neglect of these problems left it unprepared for the political and economic changes in the 1980s, when protective barriers were gradually lifted and new competitors (foreign coal, natural gas) entered markets. The limited strategic response to these changes was, however, also due to strong government control over the industry's financial and managerial decisions and the erosion in slack and resources.

\section{Conclusions}

While the transitions literature is dominated by studies of emerging innovations, this paper has demonstrated that the destabilisation of existing industries is an equally important (and interesting) parallel process. The paper's conceptual framework integrated four existing views on destabilisation, showing how the process can be understood as entailing both external pressures and endogenous responses. Commitment to the existing industry regime tends to create inertia, which delays appropriate responses to external pressures, which, in turn, causes performance problems (financial and in terms of legitimacy). Substantial performance problems weaken industry commitment to existing regimes, causing destabilisation. The two case studies confirmed the usefulness of the conceptual framework and demonstrated the multi-dimensional nature of industry destabilisation. While technical and economic drivers were crucial, their effects were mediated by socio-cultural and political factors. The cases had a reasonable fit with the phase-model, but also some substantial deviations, which related to changes in the direction of pressures and to limitations on strategic action. The case studies were further used to formulate ten important lessons about general features of destabilisation processes and specific dimensions.

To address our interest in climate change and low-carbon transitions, we end the paper with an application of some lessons to possible future destabilisation of fossil-fuel based industries (such as the car, oil, coal, electricity, and gas industries). This application is speculative, because a thorough application of the framework would require in-depth studies of the pressures and response strategies in various industries. Space constraints forbid such discussion in this paper.

An important lesson is that industries are committed to existing industry regimes, and are likely to resist major change in technical competencies, core beliefs and mission. Although

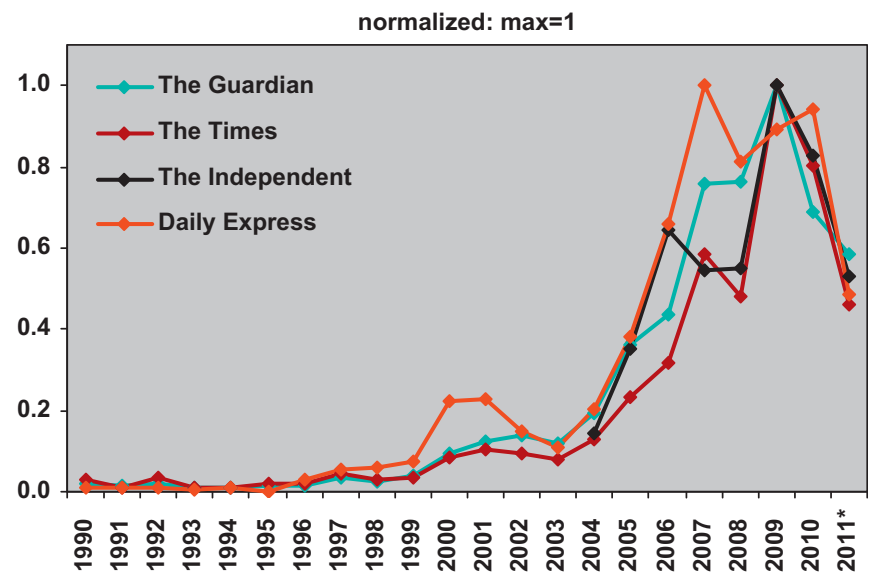

Fig. 10. Yearly number of articles in UK national newspapers containing the word 'climate change' (The graph is based on data from a keyword search in the digital archives of these newspapers. Duplicated articles were excluded. To facilitate visual comparison between different datasets, we normalized the time series so that 1 refers to the year with the maximum number of counts).

climate change exerts some pressure, fossil-fuel related industries will not simply roll over and destabilise. Instead, they are likely to resist and only gradually abandon existing regimes when social, political and economic pressures increase. In terms of our phasemodel, we can characterise the 1990 s as phase 1 , with various fossil fuel firms contesting climate change, e.g., via the Global Climate Coalition (GCC). The late 1990s can be seen as the start of phase 2 with industries acknowledging the problem and beginning to implement incremental innovations in response to increasing public concerns. ${ }^{5}$ Many industries now appear to be between phase 2 and 3 . They are still committed to existing regimes, but also explore some alternatives (carbon capture and storage, renewables and biofuels, hybrid and battery-electric cars). Many industry actors are hesitant about full commitment, because of doubts about the economic viability of alternatives. They also use political strategies to resist policies that would change the economic frame conditions (through taxes, subsidies, stricter regulations) in favour of alternatives. At present, we agree with Jones and Levy (2007: 436-437) that: "The emerging greenhouse gas regime is simply not up to the task of a radical restructuring of energy and transportation markets." This means that we are still in the early phases of destabilisation. Further destabilisation would require: greater public sense of urgency, stronger political will to introduce effective policies, more pressure from radical alternatives (wind, solar, biomass, etc.), and economic industrial problems. Our cases offer some relevant insights with regard to these pressures.

1) Climate-related crises can accelerate destabilisation when they lead to public outrage that erodes the cultural legitimacy of industries or their products and stimulates the introduction of game-changing policies. Crises have larger effects if they are preceded by long-standing debates and if feasible renewable options are available that politicians can push forward as new solutions. These indirect causal links underline the importance of articulating critical discourses and nurturing alternatives before opportunities present themselves. One complication with this lesson is the lag-effect in the climate system: by the time climate-related crises become more prominent, it may be too late to introduce effective solutions. Another

${ }^{5}$ Following the Kyoto Protocol (1997), BP, Shell, and Ford left the GCC (in 1997, 1998, and 1999). 
complication is that the 'salience' and 'macro-cultural resonance' (Geels and Verhees, 2011) of the climate change discourse seems to have weakened in recent years. Although newspaper counts are only a rough proxy of public attention, Fig. 10 suggests that the economic recession may have decreased the public sense of urgency for climate change, something that would delay low-carbon transitions and fossilfuel destabilisation.

2) Social concerns about climate change are unlikely to destabilise existing industries. Our cases show that economic pressures tend to be more important than environmental issues. But they also show that environmental issues can gain traction when they are expressed in conjunction with economic factors (e.g., alternative technologies, changing customer demands, accumulated dissatisfaction, shrinking markets). For lowcarbon transitions, this means that reform efforts, visions and renewable technologies should be linked to other attributes than climate mitigation. Examples could be improved service, quality of life issues, improved price/performance, energy independence, user freedom, etc.

3) Public support for purposive transitions depends not only on a perceived urgency of problems, but also (and perhaps more) on attractive visions of alternative futures. Public opinion was long aware of smoke problems, but not very concerned. It was not until smoke concerns became part of a broader cultural package (and new visions of modern, clean, convenient, smokeless households) that public support for change gathered momentum. For low-carbon transitions, this means that alarming climate scenarios may be less effective in generating public support than positive visions of low-carbon futures (which should include other features than low carbon emissions).

4) Existing industries often receive protection when they experience economic problems, e.g., UK coal in the 1930s, banking and the car industry in the recent economic crisis. On the one hand, these support measures are indicative of the economic and political importance of these industries. On the other hand, they may cause frustration and weaken the industry's political capital, which means they may not be bailed out in the next crisis. In the two cases policy makers became more critical of subsidies and protection, when discourses changed in later periods. With regard to low-carbon transitions, it is important to articulate a critical discourse about the $\$ 650$ billion in global annual subsidies for the consumption and production of fossil fuels (UNEP, 2011). These subsidies prop up fossil fuel industries, and their removal would greatly contribute to their destabilisation.

5) Although existing industries tend to oppose major policy change, the second case showed that policymakers can engage in purposive and ideologically motivated policy reform. The determined implementation of market reforms in the 1980s and 1990s shows that industries can be deliberately destabilised. While this reform is not entirely similar to a low-carbon transition, the example is encouraging because it shows that political determination can bring about major reforms in economic frame conditions. It is not entirely clear, however, how political will might arise for low-carbon transitions. Our cases suggest that political will is often the outcome of multiple aligning processes such as accumulated political frustration, availability of technical alternatives, pressure from public opinion, and pressure from other industries that will benefit from the policy change. A complication with this argument is that the 1980s reforms targeted an industry (coal) that was already economically weakened. Many fossil-fuel based industries, in contrast, are economically profitable, which makes it harder for policymakers to deliberately destabilise them. In this respect, most economists (e.g., Stern, 2008) emphasize the importance of carbon pricing through carbon taxes or tradable permit schemes. But experiences with the European emissions trading scheme are not entirely encouraging: (a) the carbon price is volatile (Fig. 11), which is likely to delay investments, (b) the price is relatively low (and has further decreased during 2011), which limits the incentive, (c) incentives seem

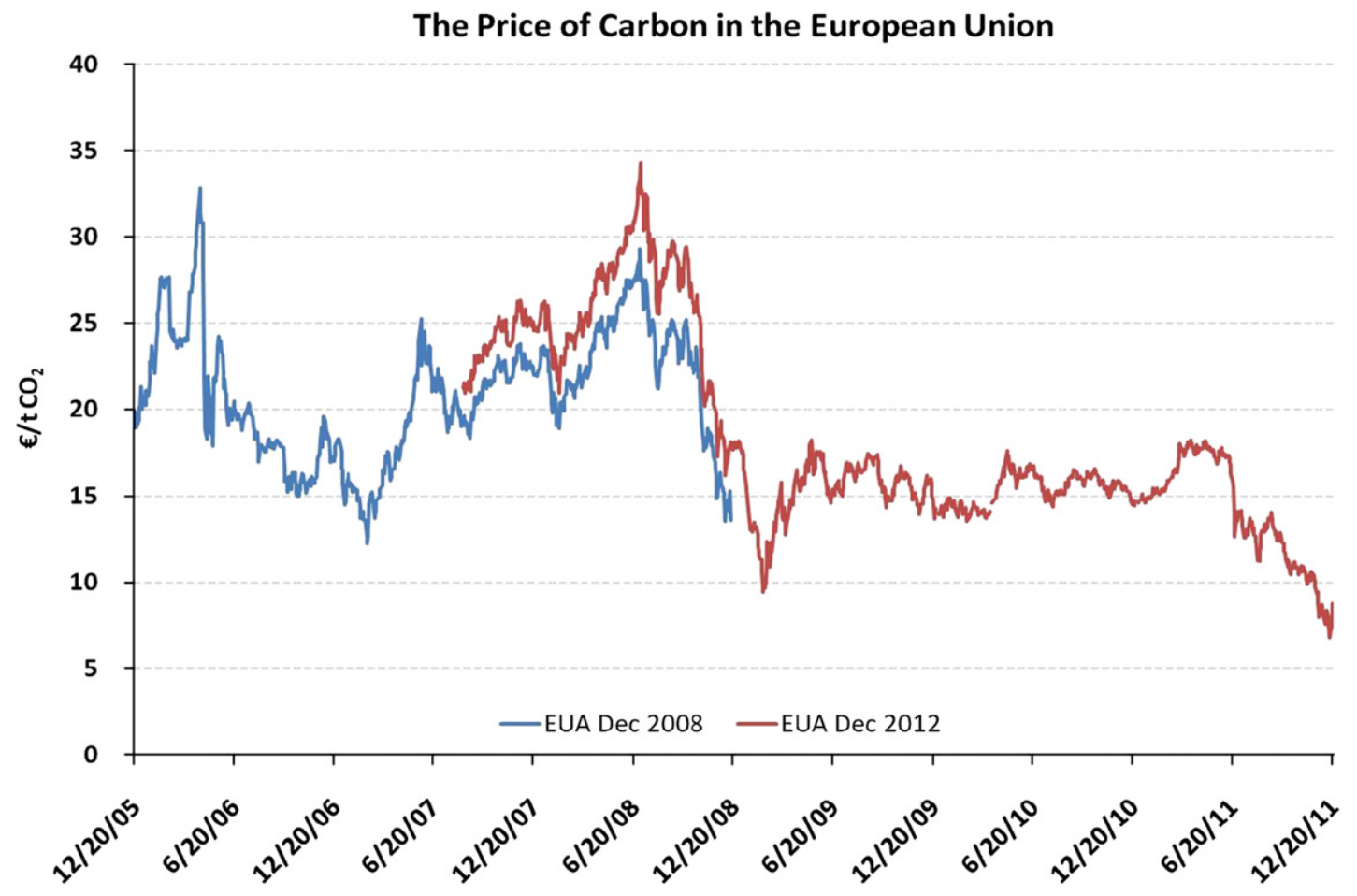

Fig. 11. Carbon price in the European emissions trading scheme.

Source: (from: www.pointcarbon.com, accessed on 9 February 2012). 
insufficient to overcome carbon lock-in of incumbent industries (Unruh, 2000), (d) current price signals lead investors to prefer incremental and close-to-market options rather than more radical and uncertain innovations, which thus face difficulties in overcoming the 'valley of death'. It is an ongoing debate if these problems are intrinsic to carbon trading schemes (which leads some actors to propose carbon taxes that provide a more certain floor price) or if the current scheme is ill designed (in which case we should see recent EUETS experiences as part of a wider learning process that may lead to better future designs). We cannot solve this important debate on carbon valuation in this article. ${ }^{6}$ But we would like to say that a focus on the design of policy instruments, should be accompanied by attention for their implementation (credibility, stability, enforcement, legitimacy), which depends on broader issues such as political will and public support, which we highlighted above.

6) While many current efforts are focused on stimulating new green options, our cases suggest that cultural criticisms and political contestations of existing systems are equally important. Although the discourses from smoke-activists, who negatively framed coal, did not immediately lead to industry destabilisation, they were important through varied indirect effects and spillovers. A concluding lesson therefore is that destabilisation is a relevant focus for advocates of sustainability transitions. Weakening the cultural, political, economic and technological dimensions of fossil-fuel related industries is just as important as stimulating green options. The bi-directional causality that we identified, suggests that both processes are two sides of the same coin.

\section{Acknowledgements}

This work has been supported by an ERC grant (No. 204246). We want to thank Bram Verhees for letting us use his data on climate change reporting in British newspapers.

\section{References}

Allen, G.C., 1970. British Industries and their Organization, fifth ed. Longmans. Arthur, W.B., 1989. Competing technologies, increasing returns, and lock-in by historical events. Economic Journal 99 (394), 116-131.

Ashby, E., Anderson, M., 1981. The Politics of Clean Air, Monographs on Science, Technology, and Society. Clarendon Press, Oxford.

Ashworth, W., 1986. The History of the British Coal Industry, Vol. 5, 1946-1982: The Nationalized Industry. Clarendon Press, Oxford.

Beynon, H., Cox, A., Hudson, R., 2000. Digging up Trouble: Opencast Coal-mining and Environmental Protest. Rivers Oram, London.

Boehmer-Christiansen, S., Skea, J., 1991. Acid Politics. Belhaven Press, London.

Chapman, J.H., 1999. The Policy Processes and the Decline of the British DeepMined Coal Industry from the Mid-1960s to 1995. PhD Dissertation, University of Sheffield.

Christensen, C., 1997. The Innovator's Dilemma: When New Technologies Cause Great Firms to Fail. Harvard Business School Press, Boston, MA

Collins, J., 2009. How the Mighty Fall, and Why Some Companies Never Give In. Random House, London.

Dintenfass, M., 1992. Managing Industrial Decline: British Coal Industry Between the Wars. Ohio State University Press.

Dutton, J.E., Dukerich, J.M., 1991. Keeping an eye on the mirror: image and identity in organizational adaptation. Academy of Management Journal 34 (3), 517-554.

Feldman, M.S., 2003. A performative perspective on stability and change in organizational routines. Industrial and Corporate Change 12 (4), 727-752.

Fine, B., 1990. Economies of scale and a featherbedding cartel?: a reconsideration of the interwar British coal industry. Economic History Review 43 (3), 438-449.
Fligstein, N., 1996. Markets as politics: a political-cultural approach to market institutions. American Sociological Review 61 (4), 656-673.

Fouquet, R., Pearson, P.J.G., 1998. A thousand years of energy use in the United Kingdom. The Energy Journal 19 (4), 1-41.

Fouquet, R., 2010. The slow search for solutions: lessons from historical energy transitions by sector and service. Energy Policy 38, 6586-6596.

Geels, F.W., 2002. Technological transitions as evolutionary reconfiguration processes: a multi-level perspective and a case-study. Research Policy 31 (8-9), 1257-1274.

Geels, F.W. A triple embeddedness framework of industrial change: understanding the co-evolution of industry with markets. Civil Society and Politics, submitted for publication.

Geels, F.W., Schot, J.W., 2007. Typology of sociotechnical transition pathways. Research Policy 36 (3), 399-417.

Geels, F.W., Verhees, B., 2011. Cultural legitimacy and framing struggles in innovation journeys: a cultural-performative perspective and a case study of Dutch nuclear energy (1945-1986). Technological Forecasting \& Social Change 78 (6), 910-930.

Giddens, A., 1984. The Constitution of Society: Outline of the Theory of Structuration. University of California press, Berkeley [etc.].

Hannah, L., 1982. Engineers, Managers and Politicians: the First Fifteen Years of Nationalised Electricity Supply in Britain. Macmillan, London.

Haveman, H.A., Rao, H., 1997. Structuring a theory of moral sentiments: institutional and organizational co-evolution in the early thrift industry. American Journal of Sociology 102 (6), 1606-1651.

Hillman, A., Hitt, M., 1999. Corporate political strategy formulation: a model of approach, participation, and strategy decisions. Academy of Management Review 24 (4), 825-842.

Jones, C.A., Levy, D.L., 2007. North American business strategies towards climate change. European Management Journal 25 (6), 428-440.

Levy, D.L., Newell, P.J., 2000. Oceans apart? Business responses to the environment in Europe and North America. Environment 42 (9), 8-20.

Lewin, K., 1947. Frontiers in group dynamics I: Concept, method and reality in social science; social equilibria and social change. Human Relations 1, 5-41.

Lorenz, E., 1994. Organizational inertia and competitive decline: the British cotton, shipbuilding and car industries, 1945-1975. Industrial and Corporate Change 3 (2), 379-403.

Lounsbury, M., Glynn, M.A., 2001. Cultural entrepreneurship: stories, legitimacy, and the acquisition of resources. Strategic Management Journal 22 (6-7), 545-564.

Nelson, R.R., Winter, S.G., 1982. An Evolutionary Theory of Economic Change. Belknap Press, Cambridge (Mass.).

Oliver, C., 1992. The antecedents of deinstitutionalization. Organization Studies 13 (4), 563-588.

Parker, M., 2000. Thatcherism and the Fall of Coal. Oxford University Press for the Oxford Institute of Energy Studies.

Phillips, M.E., 1994. Industry mindsets: exploring the cultures of two macroorganizational settings. Organization Science 5 (3), 384-402.

Porter, M., 1980. Competitive Strategy: Techniques for Analyzing Industries and Competitors. Free Press, New York.

Scott, W.R., 1995. Institutions and Organizations, second ed. Sage publications, Thousand Oaks, CA. [etc.].

Scott, P., 2006. Path dependence, fragmented property rights and the slow diffusion of high throughput technologies in inter-war British coal mining. Business History 48 (1), 20-42.

Smith, A., Stirling, A., Berkhout, F., 2005. The governance of sustainable sociotechnical transitions. Research Policy 34, 1491-1510.

Stern, N., 2008. The economics of climate change. American Economic Review 98 (1), 1-37.

Supple, B., 1987. The History of the British Coal Industry, Vol. 4, 1913-1946: The Political Economy of Decline. Clarendon Press, Oxford.

Thorsheim, P., 2006. Inventing Pollution: Coal Smoke and Culture in Britain since 1800. Ohio University Press, Athens.

Turnheim, B., Geels, F.W. The Destabilisation of Existing Regimes in Sociotechnical Transitions: Confronting a Multi-dimensional Framework with a Case Study of the British Coal Industry (1913-1970), submitted for publication.

Turnheim, 2012. The Destabilisation of Industries in Socio-technical Transitions: Theory and Cases from the British Coal Industry. Doctoral Thesis, SPRU, University of Sussex.

Tushman, M.L., Romanelli, E., 1985. Organizational evolution: a metamorphosis model of convergence and reorientation. In: Cummings, L.L., Staw, B.M. (Eds.), Research in Organizational Behavior, Vol. 7. JAI Press, Greenwich, CT, pp. 171-222.

Tripsas, M., Gavetti, G., 2000. Capabilities, cognition and inertia: evidence from digital imaging. Strategic Management Journal 21, 1147-1161.

UNEP, 2011. Towards a green economy: pathways to sustainable development and poverty eradication. A Synthesis for Policy Makers.

Unruh, G.C., 2000. Understanding carbon lock-in. Energy Policy 28 (12), 817-830.

Weitzel, W., Jonsson, E., 1989. Decline in organizations: a literature integration and extension. Administrative Science Quarterly 34 (1), 91-109.

Williams, R., 1980. The Nuclear Power Decisions: British Policies, 1953-1978. Routledge, London.

\footnotetext{
${ }^{6}$ We want to thank an anonymous reviewer for drawing our attention to this
} debate. 